\title{
RACIAL/ETHNIC VARIATION IN THE RELATIONSHIP BETWEEN EDUCATIONAL ASSORTATIVE MATING AND WIVES' INCOME TRAJECTORIES
}

\author{
Kate H. Choi \\ hchoi228@uwo.ca \\ Department of Sociology \\ University of Western Ontario \\ London, Ontario, Canada; \\ Patrick A Denice \\ pdenice@uwo.ca \\ Department of Sociology \\ University of Western Ontario \\ London, Ontario, Canada;
}

A version of this paper was published in Demography and can be found in:

https://doi.org/10.1215/00703370-10421624

Note: The authors contributed equally to this paper 


\section{ABSTRACT}

Prior work has examined the relationship between educational assortative mating and wives' labor market participation but has not assessed how this relationship varies by race/ethnicity. Using data from the National Longitudinal Survey of Youth 1979, we estimate group-based developmental trajectories to investigate whether the association between educational assortative mating and wives' income trajectories varies by race/ethnicity. The presence, prevalence, and shapes of prototypical long-term income trajectories vary markedly across racial/ethnic groups. Whites are more likely than Blacks and Hispanics to follow income trajectories consistent with a traditional gender division of labor. The association between educational assortative mating is also stronger for Whites than for Blacks and Hispanics. White wives in educationally hypogamous unions make the greatest contribution to the couple's total income, followed by those in homogamous and hypergamous unions. Black and Hispanic wives in hypogamous unions are less likely than their peers in other unions to be secondary earners. These findings underscore the need for studies of the consequences of educational assortative mating to pay closer attention to heterogeneity across and within racial/ethnic groups.

\section{KEYWORDS}

Race/ethnicity; Educational assortative mating; Women's income; Group-based trajectory models 


\section{Introduction}

Women historically received less education than men, starting in the 1960s, women's participation in tertiary education increased more rapidly, and their college graduation rates eventually surpassed those of men (Esteve et al. 2012; Van Bavel et al. 2018). A consequence of this reversal is the rising share of marriages in which women have an educational advantage over their husbands (Van Bavel et al. 2018). Such changes have kindled questions about the relationship between educational assortative mating and women's labor force participation (e.g., Dribe and Nystedt 2013; Qian and Shen 2021; Vissar and Fasang 2018).

Prior work on this topic has examined the relationship between educational assortative mating and wives' labor market participation in the population overall while controlling for race/ethnicity (e.g., Qian 2018, Qian and Shen 2021). Thus, we know little about whether and how this association differs by race/ethnicity. Growing evidence, however, suggests such variation. Because of systemic inequalities in the labor market, Black wives are less able than others to adhere to the traditional male breadwinner-female homemaker model (Chetty et al. 2020; Coontz 2005; Wagmiller 2007). Racial/ethnic groups may also subscribe to different cultural beliefs about married women's labor force participation (Kane 2000). Black families may emphasize women's self-sufficiency, whereas Hispanic families may emphasize familism and women's roles as mothers (Dow 2019; Kane 2000). Recent studies have also highlighted the differential consequences of family organization on distinct racial/ethnic groups, underscoring the importance of conducting analyses specific to each racial/ethnic group (Cross 2019 forthcoming; Fomby et al. 2010; Williams and Baker 2021).

Using data from the National Longitudinal Survey of Youth 1979, we examine variation in wives' long-term income trajectories by educational assortative mating and race/ethnicity. We 
first use group-based trajectory models to identify prototypical pathways of wives' share of couples' total income during the first 20 years of marriage separately among White, Black, and Hispanic women. We then compare the association between educational assortative mating and trajectory group membership by race/ethnicity. Finally, we assess the extent to which differences in wives' family background, gender attitudes, socioeconomic status in young adulthood, and partnership traits contribute to variation in wives' income trajectories by educational assortative mating. Like prior work on the consequences of assortative mating, we focus on married individuals (Breen and Salazar 2011; Bucca 2018; Schwartz and Han 2014).

We contribute to the literatures on union formation and racial/ethnic inequality in several ways. First, we conduct analyses specific to each racial/ethnic group. Like recent work (Cross 2019; Fomby et al. 2010; Williams and Baker 2021), we show how the association between family organization and family members' well-being varies by race/ethnicity. Recent studies have largely focused on the impact of family structure on child and adolescent outcomes (Cross 2019; Fomby et al. 2010). We examine how educational assortative mating shapes married women's socioeconomic outcomes. Second, we use a dyadic approach and examine how couples' joint traits—specifically, wives' and husbands' relative education levels—shape income trajectories, recognizing the interdependence of wives' and husbands' lives and economic conditions (Qian 2018). Past studies have focused primarily on individual or partner effects (for exceptions, see Bucca 2018; Qian 2017, 2018; Qian and Shen 2021). Marital sorting along educational lines can affect women's income trajectories, net of wives' and husbands' education, by shaping intracouple power dynamics and household division of labor (Miller 2020). Third, we join the small yet growing body of work that uses group-based trajectory models to describe the longterm, dynamic nature of wives' income trajectories over time (Damaske and Frech 2016; Qian, 
2018; Visser and Fasang 2018; Weisshaar and Cabello-Hutt 2020). The trajectories described in this analysis allow for a more granular and holistic understanding of prototypical pathways of wives' income (Marti 2008). We identify clusters of trajectories distinguishable by wives' income levels, changes in their labor market participation, and the timing and duration of the various states (Nagin 2005).

We use educational homogamy to refer to marriages involving spouses with similar levels of education, hypogamy to refer to marriages in which wives have more education than their husbands, and hypergamy to refer to marriages in which wives have less education than their husbands. We use relative levels of education to describe whether wives have similar, higher, or lower levels of education than their husbands.

\section{Background}

\section{Theoretical Frameworks}

Three theoretical perspectives inform our expectations about the relationship between educational assortative mating and wives' relative earnings. Exchange theory defines the household as a cooperative unit seeking to optimize household production (Becker 1974). The spouse with the higher earnings potential and consequently higher comparative advantage in the labor market specializes in paid work, while the other partner specializes in home production (Becker 1974, 1981). Owing to gender inequalities in the labor market, wives have traditionally specialized in unpaid housework, and husbands have traditionally specialized in paid work (Becker 1974, 1981). Because partners specialize in different spheres, women and men engage in positive assortative mating for all traits unrelated to their earnings potential (Becker 1974). In recent decades, families have transitioned from single-earner to dual-earner households 
(Oppenheimer 1988; Sweeney 2002). More schooling is associated with higher earnings. Thus, in the absence of a strictly gendered division of labor, wives with higher education relative to their husbands will contribute more toward the couple's total earnings than their peers with relatively lower levels of education (Becker and Strauss 1956).

Bargaining theory assumes that each spouse has a unique set of interests (Lundberg and Pollak 1996; Visser and Fasang 2018). Given their competing interests, spouses continually negotiate to optimize their utility (Lundberg and Pollak 1996). The spouse with more education likely has a stronger bargaining position because of their fallback potential for paid work outside marriage. This advantage can be used to negotiate out of housework (Miller 2020). Like exchange theory, this framework predicts that wives with more relative education will contribute a greater share of the couple's total earnings.

Gender theory argues that gender beliefs interact with the constraints in work and family life to shape women's work trajectories (Blair-Loy and Dehart 2003; Damaske and Frech 2016; Esping-Andersen and Billari 2015; Udansky 2011; West and Zimmerman 1987). For instance, married women's ability to cut back on paid labor following childbirth is determined by their views about the importance of women's continued labor force participation and their need to contribute to the household economy (Clawson and Gerstel 2015; Goldscheider et al. 2015). Women with lower levels of education generally adhere to more traditional gender norms than those with higher levels of education, but they may not be able to cut back because of their husbands' limited earnings and their family's reliance on their income (Clawson and Gerstel 2015; Udansky 2011).

How gender beliefs influence the relationship between educational assortative mating and wives' income trajectories is unclear. People are generally averse to educationally hypogamous 
unions because such unions deviate from traditional gender norms (Bertrand et al. 2015; Fisman et al. 2006; Hitsch et al. 2010). Those in hypogamous unions may be a select group less inclined to espouse traditional gender roles. Their partnerships will be more egalitarian, and wives will contribute a greater share of the couple's total income than those in homogamous or hypergamous unions. The opposite could also be true. Traditional gender roles emphasize men's role as the primary breadwinner and women's role as homemaker (Bittman et al. 2004; Brines 1994; Gonalons-Pons 2015; Gonalons-Pons and Gangl 2021; Lu et al. 2017; West and Zimmerman 1987). Educational hypogamy may be viewed as a symbol of nonnormative power dynamics between spouses (Tichenor 2005). Married couples may try to compensate for the gender nonconformity in one dimension of the union (i.e., relative education) by exaggerating gender normativity in other areas, such as wives in hypogamous unions forgoing high-paying jobs (Cooke 2006).

These perspectives have been criticized for their White middle-class bias (Landor and Barr 2018; West and Fenstermaker 1995). We extend this literature by examining whether the predictions informed by these perspectives extend to women in racial/ethnic groups in which large shares do not belong to the middle class. Exchange and bargaining theories have also been criticized for assuming that single individuals are equipped with perfect and costless information about potential partners (Oppenheimer 1988). As men and women receive more training and men's economic positions have become more precarious, there is greater uncertainty regarding the quality of potential partners, especially about their long-term economic potential (Oppenheimer 1988). We assess whether these models' predictions extend to women in racial/ethnic groups who generally experience more job precariousness and economic 
uncertainty. Conceivably, the association between educational assortative mating and wives' income trajectories may be weaker for such groups.

\section{Prior Empirical Work on Educational Assortative Mating and Wives' Relative Income}

Research has offered mixed accounts of the relationship between educational assortative mating and wives' labor market activities. Many have found that wives' higher relative education is associated with greater labor market participation and higher wages. Van Bavel and Klesment (2017), for instance, used data from the European Union Statistics on Income and Living Conditions and found that wives in hypogamous unions had higher relative earnings and were less likely to interrupt their labor market activities following motherhood than their peers in hypergamous or homogamous unions. Using NLSY79 data, Qian (2018) found that women in hypogamous unions earned more than those in homogamous or hypergamous unions. Qian and Shen (2021) also found that wives with an educational advantage over their husbands earned more, but only before motherhood. By contrast, Dribe and Nystedt (2013) used data from the Swedish population registry to show that marrying someone with comparatively less education inhibits wives' earning growth. Visser and Fasang (2018) found that the association between educational assortative mating and later-life employment trajectories was minimal. What matters instead are the levels of education. Highly educated homogamous couples tend to be in stable, high-status, dual-earner households; homogamous couples with lower levels of education are in low-status, single-breadwinner arrangements. These mixed accounts likely emerged because the studies examined different outcomes and dissimilar populations with distinct gender norms. 


\section{Why Might the Relationship Between Educational Assortative Mating and Wives' Income Trajectories Vary by Race/Ethnicity?}

Research examining the relationship between educational assortative mating and wives' income and work trajectories has generally presented average effects for the overall population while controlling for race/ethnicity (Qian 2017, 2018; Qian and Shen 2021). Recent studies, however, have shown that the impact of family structure varies across racial/ethnic groups, highlighting the need analyses specific to each racial/ethnic group when examining the consequences of family organization (Cross forthcoming; Williams and Baker 2021). Many interrelated factorsincluding wives' family background, gender beliefs, socioeconomic traits, and partnership characteristics - may contribute to racial/ethnic differences in the association between educational assortative mating and wives' income trajectories.

\section{Family Background}

Black and Hispanic women generally grow up in families with fewer economic and educational resources than White women (Edelman and Jones 2004; McLanahan and Jacobsen 2015; Slopen et al. 2016). Thus, Black and Hispanic women attain fewer years of schooling than White women, reducing their attractiveness in the labor and marriage markets (Cheng et al. 2019; Kao and Thompson 2003). Growing up in disadvantaged families may also alter views about married women's labor force participation. Black and Hispanic women are more likely than White women to grow up in households where all adult household members contribute to the household economy. They are less likely than White women to perceive specialization in housework as a viable work trajectory for women (Dow 2019). Black women are also more likely than their White peers to be born to single mothers or to experience parental separation (Brown et al. 
2016). Women's and children's income decreases following divorce (Peterson 1996). As grownups, they may be less likely than White women to forgo or interrupt their labor market activities to avoid economic hardship following potential divorce, irrespective of their educational assortative mating patterns.

\section{Gender Beliefs}

Black families are more likely than non-Black families to emphasize women's self-sufficiency and to perceive paid work as a necessary dimension of womanhood (Dow 2019). Hispanic families emphasize familism, which underscores women's caregiver roles (Landale et al. 2006). Middle-class White families emphasize the intensive mothering paradigm (Hays 1996). Therefore, irrespective of their educational assortative mating patterns, Black women may be less likely than their White and Hispanic counterparts to "do gender" and to be secondary earners during their marriage.

Racial/ethnic disparities in the normativity of educational hypogamy may also generate differences in wives' income trajectories. White women's college graduation rates have exceeded those of White men starting with the 1960 birth cohort (DiPrete and Buchmann 2013; McDaniel et al. 2011; Van Bavel et al. 2018). By contrast, Black women's college graduation rates have exceeded those of Black men since the 1930 birth cohort (Cohen and Nee 2000; McDaniel et al. 2011). Hypogamous unions may thus be more normative among Black couples than among White and Hispanic couples (see Figure A1, shown in the online appendix along with all other figures and tables designated with "A"). In this way, Black couples may be less likely than non-Black couples to exaggerate gender normativity in other dimensions of married life, including wives' labor force participation. The opposite may be true for Hispanic couples. 
Hence, educational assortative mating may be more weakly associated with Black wives' employment trajectories but more strongly tied to Hispanic wives' employment relative to White women.

\section{Socioeconomic Characteristics}

Black and Hispanic women attain less schooling than White women (Kao and Thompson 2003). As a result, they may have greater difficulty obtaining stable and high-paying employment early in their transition to adult economic roles and over the long run (Cancio et al. 1996; Damaske 2011; Reid and Padavic 2005). These traits may also render them unattractive mates, prolonging their marital search (Schneider et al. 2019). In particular, Black women are more likely than White and Hispanic women to marry at older ages and have a child from a previous union (Choi et al. 2022; Coverdill et al. 1996). Irrespective of educational assortative mating, Black wives may have a greater need to work for pay than their peers in other groups to finance the expenses of children from previous unions because stepfathers invest less in stepchildren than biological fathers spend on biological children (Cherlin 1978; Raley and Sweeney 2020; Thompson et al. 1994).

\section{Partnership Characteristics and Union Trajectories}

Black and Hispanic women encounter less favorable marriage markets than White women for several reasons. Their unfavorable economic prospects reduce their attractiveness as potential spouses (Schneider et al. 2019). Furthermore, cultural stereotypes often depict Black women as aggressive, unfeminine, and defying conventional standards of beauty (Adeyinka-Skold 2020; Bany et al. 2014; Lin and Lundquist 2013). Such stereotypes can reduce Black women's 
attractiveness as potential partners. Because of structural inequalities in the labor market, Black and Hispanic men have greater difficulty securing stable and high-paying jobs (Cheng et al. 2019; Storer et al. 2020; Sun 2020). More than $80 \%$ of marriages are ethnoracially endogamous (Livingston and Brown 2017); thus, Black and Hispanic women may encounter a scarcity of partners with favorable economic prospects. For Black women, the mass incarceration of Black men may exacerbate this problem (Raley et al. 2015; Western and Sirois 2019). Together, these factors compel Black and Hispanic women to cast a wider net, which increases their prospect of marrying relatively less educated partners. Even if they marry a spouse with equal or higher levels of education, Black and Hispanic women's spouses may possess traits unrelated to education that render them unattractive in labor markets. The association between educational assortative mating and wives' income trajectories may therefore be less pronounced for Black and Hispanic women, who have a greater need to contribute continuously to the household economy, than for White women.

Racial/ethnic disparities in union trajectories may also contribute to differences in the association between educational assortative mating and wives' income trajectories. Relative to White and Black marriages, a lower share of Hispanic marriages is preceded by cohabitation (Choi et al. 2022). Cohabiting couples are less likely than married couples to pool their resources (Smock 2000), and couples who cohabited before marriage often continue these practices after they marry (Smock 2000). The higher shares of Hispanic women transitioning directly to marriage suggest that they will be more likely than White and Black women to specialize in housework, irrespective of their assortative mating patterns.

\section{Methods}




\section{Data}

We use 28 waves of data from the National Longitudinal Survey of Youth 1979 (NLSY79), a nationally representative survey of 6,283 women and 6,403 men who were aged 14-22 in 1979 . The NLSY79 surveyed respondents annually until 1994 and biennially afterward, collecting information about respondents' major life events, including marriage, childbirth, and employment. The survey asks about respondents' and their spouses' educational attainment, allowing us to capture couples' educational assortative mating patterns. It also collects detailed information about married respondents' and their spouses' employment histories, including income and correlates of labor force participation. Black and Hispanic respondents were oversampled, providing us with samples large enough to disaggregate wives by race/ethnicity and educational assortative mating.

\section{Sample}

Our sample consists of 3,469 married women in their first marriages. We focus on wives based on prior work showing that educational assortative mating matters more for women's than men's long-term outcomes (Choi et al. 2020; Qian 2018). We examine first marriages because educational assortative mating patterns (Shafer 2012), the intrahousehold division of labor (IshiiKuntz and Coltrane 1992), and marital dissolution rates (Sweeney 2010) differ between first and later marriages. From the initial 6,283 female respondents, we exclude those who were part of the discontinued military and the economically disadvantaged non-Black, non-Hispanic oversamples $(n=1,357)$. We also exclude respondents who never married $(n=854)$, who never lived with their spouses ( $n=248)$, or who were missing key information about their spouses, including their education $(n=233)$. We exclude respondents without any information on the 
dependent variable between ages 18 and 55 (prime working years) or in the initial 20 years of their first marriage $(n=122)$. We organize the data for the remaining 3,469 female respondents into person-year files. After excluding person-year records in which the spouses are not aged 1855, after 20 years of marriage, and missing information on the dependent variable, our sample yields 29,720 person-years (see Table A1).

\section{Measures}

\section{Dependent Variable}

Wife's share of a couple's total annual income during each of the first 20 years of marriage is the percentage of a couple's total annual income that the wife earned. Like prior work (Qian 2018), we define wives' and husbands' income as their annual wage and salary earnings. Their income is adjusted to constant 2018 dollars using the Annual Average Consumer Price Index Research Series (CPI-U-RS) (see Schwartz 2010), and extreme values are recoded using weighted values at the 1 st and 99th percentiles. In robustness checks, we examined a related outcome - wife's share of the couple's total annual hours worked — and constrained our analyses of wives' income share to the first 10 and 15 years of marriage. Membership in trajectories obtained using these alternative strategies correspond well, and our core results are generally consistent.

\section{Key Independent Variables}

Wife's racelethnicity distinguishes non-Hispanic Black ("Black”); Hispanic; and non-Black, nonHispanic ("White") married women. 
To measure educational assortative mating, we first classified wives and husbands into four levels of education: (1) no high school diploma, (2) high school diploma or GED, (3) some college, and (4) at least four years of college. We then cross-classified wives' and husbands' education to distinguish couples in unions that are homogamous (wives and husbands have the same level of education), hypogamous (wives have more schooling than their husbands), and hypergamous (wives have less schooling than their husbands). Table A2 cross-tabulates educational assortative mating with race/ethnicity. In sensitivity analyses, we obtained similar results using alternative measures of educational assortative mating, including the difference between wives' and husbands' years of schooling or education levels.

\section{Other Correlates of Trajectory Group Membership}

Our models also include important correlates of wives' income and assortative mating patterns (Choi and Tienda 2017, 2021; Damaske and Frech 2016; Mare 1991). All correlates are measured before or at the onset of the marriage. We capture family background with family structure at age 14 (two-parent families or others), mother's education (no high school or high school or more), and maternal employment (yes or no).

To capture the extent to which respondents adhere to traditional gender beliefs, we construct an index based on respondents' agreement with each of eight items ${ }^{1}$ : (1) a woman's

\footnotetext{
${ }^{1}$ These questions were asked in 1979, 1982, 1987, and 2004. Respondents answered on a 4-point scale of strongly disagree to strongly agree; items 6-8 are reverse-coded. We use the responses from the premarital wave closest to the respondents' marriage date. We also constructed a gender
} 
place is in the home, (2) wives do not have time for employment, (3) wives' employment leads to more juvenile delinquency, (4) it is better if the man is the achiever outside the home and the woman takes care of the family, (5) women are happier if they take care of their children, (6) a working wife feels more useful than one who doesn't hold a job, (7) employment of both parents is necessary to keep up with the high cost of living, and (8) men should share the work around the house with women (Cronbach's alpha $=.73$ ). Higher scores on this standardized scale (with a mean of 0 and a standard deviation of 1) indicate more traditional gender beliefs. Because global attitudinal measures may not necessarily align with people's concrete aspirations for their own family arrangements (Herman and Campbell 2012), we also include whether the respondent anticipates working at age 35 (yes or no) and their anticipated total fertility (none, one, or two or more children). ${ }^{2}$

We capture wives' socioeconomic status during young adulthood using respondents' level of education (less than high school, high school graduate, some college, at least four years of college), unemployment status in the year before marriage (employed, unemployed, or missing), having a child from a prior union (yes or no), and age at marriage (15-19, 20-24, 2529 , or $30+)$.

index when respondents were aged 18-22. Results using the two gender belief indices were similar.

${ }^{2}$ Covariates of trajectory group membership consist of respondent traits that are determined before or at the start of marriage. Anticipated fertility and premarital childbearing allow us to incorporate the influence of childbearing on wives' income trajectories. 
Covariates capturing partnership traits include husband's income in the year closest to marriage onset, measured categorically relative to the poverty line (below, 100\% to $199 \%$, $200 \%+$ of the poverty line); ${ }^{3}$ the age difference between spouses (wife is older, husband is up to four years older, husband is at least five years older); and premarital cohabitation (yes vs. no).

\section{Analytic Strategy}

We first estimate group-based trajectory models, a type of finite mixture model, to identify trajectories of the share of couples' total annual income that White, Black, and Hispanic wives contributed during each of the first 20 years of marriage. These models identify latent clusters of wives following prototypical pathways to describe the timing, duration, and sequencing of their income over time (Nagin 2005). These models differ from hierarchical or growth curve models because they focus on group-specific trajectories rather than within-individual trajectories (Damaske and Frech 2016; Nagin 2005). Because these models pool data points across a given group, attrition via survey dropout or separation has a more limited impact on our ability to describe long-run pathways of women's labor force participation than would be the case for growth curve models. A more detailed explanation of these models can be found in the online appendix. We estimate these models separately by racial/ethnic group to relax the assumption that a consistent set of trajectories describes the long-term income pathways among White, Black, and Hispanic married women.

\footnotetext{
${ }^{3}$ The NLSY79 collected the husband's income during the first year of marriage. The husband's income before marriage is available for couples who cohabited before marriage.
} 
Next, we estimate multinomial logistic regression models predicting the competing odds of membership into each trajectory group. Model 1 begins with the zero-order association between educational assortative mating and wives' income trajectory group membership. We iteratively add women's family background (Model 2), gender beliefs (Model 3), socioeconomic status (Model 4), and partnership traits (Model 5). Rescaling and attenuation bias may confound odds ratios but do not affect average marginal effects (AME) when comparing coefficients across multinomial logistic regression models (Kohler et al. 2011; Mize 2019). Therefore, we also compute the predicted percentages of trajectory group membership for each model and compare the differences (AMEs) obtained from each model to assess the extent to which family

background, gender beliefs, socioeconomic status, and partnership traits explain the relationship between educational assortative mating and trajectory group membership for White, Black, and Hispanic wives. All models are weighted and run separately by race/ethnicity.

\section{Results}

Table 1 reports our sample characteristics by race/ethnicity and educational assortative mating. Educational homogamy is the most common pattern across all racial/ethnic groups, and hypogamy is the least common. Consistent with prior research (e.g., Hummer and Hamilton 2010), White wives are more likely than Black and Hispanic wives to grow up in two-parent households, to be reared by working mothers, and to have mothers with at least a high school diploma. Similarly, White wives completed the most schooling. A higher share of Black women married at older ages, and they appear more egalitarian in their family attitudes than White or Hispanic women. Among Black and White wives, those in educationally hypergamous unions adhere more to traditional gender beliefs than those in other unions. The pattern is less 
pronounced among Hispanic wives, who generally have more traditional family attitudes. Black wives are also more likely to anticipate working at age 35 and to have fewer children than White and Hispanic wives. A higher share of Black women than White women are married to men whose incomes fall below the poverty line across educational assortative mating categories. For example, $18 \%$ of White women in hypergamous unions and $14 \%$ of other White women have husbands with incomes below the poverty line. These figures compare with $28 \%$ and $25 \%$, respectively, for Black women. That Black women have husbands who consistently earn less than White women suggests that a higher share of Black wives may need to contribute to their household's finances through paid employment regardless of their educational assortative mating patterns.

[Set Table 1 about here]

\section{Identifying Wives' Long-Term Income Trajectories}

We highlight the variation in wives' income trajectories over the first 20 years of marriage, both across and within racial/ethnic groups. Wives' income trajectories do not follow a single average or unidirectional trajectory of increase or decline. Rather, there are multiple distinct trends: wives' contributions to couples' total income decline at various rates, hold relatively steady, and even increase over time. Furthermore, the same set of pathways does not obtain for White, Black, and Hispanic wives.

As in prior work (e.g., Damaske and Frech 2016; Qian 2017; Weisshaar and Cabello-Hutt 2020), we select the number of trajectory groups based on both empirical and substantive criteria, including parsimony, trajectories' distinctiveness, group sizes, and prior empirical and theoretical work (Nagin 2005). Table 2 presents two commonly used measures of model fit-the average posterior probabilities (APP) of group assignment and Bayesian information criterion 
(BIC) - for models with three to eight groups. Table A3 provides the model parameters describing each trajectory's shape from our preferred solutions.

\section{[Set Table 2 about here]}

Among White wives, all solutions with three to seven pathways have APPs above the conventional .700 threshold and decreasing BIC values. The solution with six groups best and most parsimoniously captures the variation in White women's income trajectories. The six-group solution improves upon the five-group solution by allowing us to distinguish wives who began their marriages as primary earners but became secondary earners from wives who started as equal earners before becoming secondary earners. Although wives in both groups decreased their contribution to couples' total income, they may differ qualitatively in their adherence to traditional norms about gender division of labor.

For Black wives, solutions with three to five trajectories have APPs above .700. Contrary to models with fewer groups, the five-pathway solution distinguishes wives who transitioned from equal to primary earners from wives who were consistently the primary earner. The level at which women start—as either an equal or primary earner—marks an important difference and suggests the extent to which Black women could rely on husbands to support their families at the onset of marriage.

Among Hispanic wives, solutions with between three and seven groups have APPs above .700. We chose the five-pathway over the six- and seven-group solutions to avoid groups with overly small cell counts. The five-group solution improves upon solutions with fewer groups by 
distinguishing wives who were consistently equal earners from wives who began marriage as secondary earners and became equal earners later in the marriage. ${ }^{4}$

\section{Describing Wives' Long-Term Income Trajectories}

Figure 1 and Table 3 summarize White, Black, and Hispanic wives' prototypical income trajectories. White wives are most likely to follow income trajectories consistent with traditional gender norms. For example, just under half of the White wives were consistently secondary earners. ${ }^{5}$ One of these trajectories (i.e., secondary earners but at higher contributions) is not present among either Black or Hispanic women. White women are also more likely than Black and Hispanic women to follow trajectories characterized by a declining income share over time. Approximately one in five White women decrease their income contribution over time: $15.7 \%$ follow the "from equal to secondary" pathway, and another $4.1 \%$ follow the "from primary to secondary" pathway. In comparison, only $10 \%$ of Black women and $14 \%$ of Hispanic women decrease their income contributions over time. Only one of these two decreasing pathways is found among Black and Hispanic women. White women are also the only group for whom increasing pathways are not present. Roughly $14 \%$ to $15 \%$ of Black and Hispanic wives increase their contribution to the couple's total income over time.

\footnotetext{
${ }^{4}$ For Blacks and Hispanic women, we conducted robustness checks using three and four trajectory groups and obtained generally consistent results.

${ }^{5}$ Roughly $20 \%$ of White wives consistently contribute roughly a third of the couple's total income ("consistent high secondary earner"). Another quarter of Whites consistently contribute $10 \%$ or less of the couple's total income (“consistent low secondary earner”).
} 
[Set Figure 1 about here]

[Set Table 3 about here]

\section{Differences in Wives' Trajectory Membership by Educational Assortative Mating}

We present the full results from our multinomial logistic regression models predicting the probability of trajectory group membership separately by race/ethnicity in Tables A4-A6. Figure 2 illustrates the results from Model 1, showing the predicted percentages of trajectory group membership by educational assortative mating within racial/ethnic groups and highlighting statistically significant differences between pairs of educational assortative mating categories (the AMEs). Table 4 presents the AMEs from Figure 2 and the extent to which each bundle of additional covariates explains these differences. In Table 4, we focus on trajectories with statistically significant differences in unadjusted AMEs (full results available upon request). ${ }^{6}$

[Set Figure 2 about here]

[Set Table 4 about here]

\section{White Wives' Income Trajectories}

Model 1 suggests a strong link between trajectory group membership and educational assortative mating among White women. White women in hypogamous unions are less likely than other White wives to follow income trajectories consistent with a traditional gender division of labor. For example, $19 \%$ of wives in hypogamous unions consistently contributed to couples' income at

\footnotetext{
${ }^{6}$ We estimate race-specific models, precluding us from directly testing racial/ethnic differences. In supplementary analyses, we pool our sample and estimate our models across all racial/ethnic groups (results available in Figure A2 and Tables A7 and A8). Trajectory groups estimated with the pooled sample most resemble those of White women.
} 
relatively low levels, compared with $27 \%$ in homogamous unions and $39 \%$ in hypergamous unions. By contrast, White women in hypogamous unions are more likely to follow pathways in which they are consistently an equal earner or the primary earner.

Our additive models (Table A4) show that adherence to traditional gender norms, expecting to have more children, and unfavorable labor market outcomes are associated with higher odds of following trajectories consistent with a traditional gender division of labor. Conversely, growing up in a two-parent family and marrying men with higher earnings are associated with lower odds of consistently being the primary earner. Similarly, marrying men with higher earnings, having a child from a prior union, and having an older husband are associated with lower odds of decreasing their income contribution to become a secondary earner.

Next, we assess whether wives' early socioeconomic status, gender beliefs, sociodemographic characteristics in early adulthood, and partnership traits explain the differences in trajectory group membership by educational assortative mating among White women. Table 4 indicates that their early sociodemographic traits have a larger explanatory power than the other factors. For example, adjusting for wives' sociodemographic traits in early adulthood explains roughly a quarter of the difference in the share of wives who are consistently low secondary earners by educational assortative mating. These findings suggest that White wives in hypergamous unions are more likely than those in homogamous unions to have largely specialized in housework, partly because they have lower education levels and marry at younger ages. Net of these differences, the difference in the share of wives in homogamous and hypogamous unions who transition from equal to secondary earners increases by $21 \%$. This 
result suggests that the percentage of wives in homogamous unions who make this transition would have been lower if it were not for their lower education levels.

Much of the variation in White wives' income trajectories by educational assortative mating remains after we introduce all the covariates. Differences in family background and gender beliefs explain a smaller portion of the variation in wives' income trajectories by educational assortative mating than women's early socioeconomic traits. By contrast, differences in partnership traits suppress disparities in the likelihood of being a consistently low secondary earner between those in hypergamous and homogamous. The share of wives in hypergamous unions who are consistently low secondary earners would have been $8 \%$ higher than the corresponding share for women in homogamous unions if it were not for the tendency among women in hypergamous unions to wed partners with lower earnings.

\section{Black Wives' Income Trajectories}

Differences in Black wives' income trajectories are largely observed between those in hypogamous and other unions. Black wives in hypogamous unions are less likely to follow the pathway of being a consistently low secondary earner but more likely to become the primary earner at some point during the marriage. For example, $13 \%$ of Black women in hypogamous unions increase their earnings contribution from parity with their husbands to become the primary earner over time, compared with $4 \%$ of those in hypergamous marriages (see Figure 2).

Table A5 shows that unemployment before marriage is positively associated with Black wives' odds of being a low secondary earner. Marrying a husband with higher earnings is associated with lower odds of following trajectories in which the wife is a primary earner at some point during their marriage. Contrary to White wives, Black wives who anticipate having 
more children have lower odds of being consistently secondary earners, as do Black wives who have some college education.

Family background and gender beliefs explain little of the variation in Black wives' income trajectories by educational assortative mating. Wives' socioeconomic status during early adulthood explains a larger share of the differences in odds of being a low secondary earner by educational assortative mating than other covariates. Yet, unlike our findings for White women, partnership traits explain the lion's share of the disparities in the probability that Black women follow trajectories in which the wife is the primary earner at some point during the marriage. For example, adjusting for differences in partnership traits - including the husband's income and the age gap between wives and their husbands — substantially reduces the hypogamoushypergamous union disparity in the probability of following the pathway of being consistently the primary earner.

\section{Hispanic Wives' Income Trajectories}

As seen for Black wives, differences in wives' trajectories among Hispanic women are largely observed between those in hypogamous and other unions. Hispanic wives in hypogamous unions are less likely than those in hypergamous unions to follow the pathway of being consistently a low secondary earner. Conversely, they are more likely than those in hypergamous or homogamous unions to be consistently the primary earner. Hispanic wives in hypogamous unions are also more likely to transition from equal to secondary earners. Other covariates in Models 2-5 in Table A6 generally operate as expected. For instance, unemployment before marriage is associated with higher odds of consistently being a low secondary earner or a secondary earner early in marriage and lower odds of consistently being the primary earner. 
Marrying a husband with high earnings is associated with lower odds of being the primary earner.

As we found for White and Black wives, family background tends to explain a smaller share of the variation in Hispanic wives' income trajectories by educational assortative mating than other factors. And as seen for Black but not White women, partnership traits explain a large share of the difference in Hispanic wives' likelihood of consistently being the primary earner between those in hypogamous and other unions. Hispanic wives' early sociodemographic traits also suppress differences in wives' likelihood of consistently being the primary earner between those in hypogamous and other unions. Gender beliefs suppress differences in the probability of decreasing their contribution from equal to secondary earner between those in hypogamous and other unions. Stated differently, an even greater share of Hispanic wives in hypogamous unions would have followed the trajectory of being consistently the primary earner rather than consistently an equal earner if it were not for the former's higher likelihood of adhering to nontraditional beliefs. The magnitude of the suppressor effect is larger for Hispanic than for Black women.

\section{Limitations}

Our study has some limitations. First, we focus on married women. Black women have lower marriage and higher divorce rates than non-Black women. Given the economic prerequisites to marriage and the role of economic strain in fomenting divorce (Edin and Kefalas 2004; Raley and Bumpass 2003), the Black wives in our sample are positively selected in terms of socioeconomic traits and are more similar to White women than the average Black woman. We may thus understate Black-White differences. That we find such stark differences between Black 
and White wives' income trajectories despite the selectivity of our sample underscores the centrality of paid work in Black women's lives. It also highlights that inequalities in the labor market by race/ethnicity contribute to disparities in how wives organize their activities.

Second, the NLSY79 focuses on late baby boomers, who largely transitioned into first marriages before the mid-1980s. Gender differences in educational attainment, assortative mating, work-family arrangements, and marriage and divorce rates have since changed (Schwartz and Han 2014; Schwartz and Mare 2005). Similar to the relationship between educational assortative mating and divorce rates (Schwartz and Han 2014), differences in wives' income trajectories by educational assortative mating may have become smaller for later cohorts given the rising share of educationally hypogamous unions; the continued increase in egalitarianism; and the growing convergence between Black and other women's family behaviors, including rising age at marriage, higher nonmarital fertility, and lower marriage rates (Cherlin 2021; Landry 2000). Simultaneously, a recent study found that the trend toward gender equity may have stalled or even reversed since the mid-1990s (Pepin and Cotter 2018). Furthermore, recent studies have demonstrated that gender inequalities in housework and women's retreat from the labor market during the COVID-19 pandemic offer evidence of the persisting influence or reemergence of the male breadwinner-female homemaker model of marriage (Carlson et al. 2022; Collins et al. 2000).

Finally, we tested the extent to which wives' family background, gender beliefs, socioeconomic status, and partnership traits help pattern income trajectories among White, Black, and Hispanic women. This is not an exhaustive list of mechanisms that may contribute to variation in women's income pathways. It excludes potential correlates such as inequalities in the labor market, discrimination, the husband's gender attitudes, and the husband's 
sociodemographic traits (e.g., race/ethnicity and nativity status). For example, interracial couples' socioeconomic circumstances often fall in between those of their same-race counterparts (Gullickson 2006), implying that the inability to control for husband's race may understate racial/ethnic disparities in the association between educational assortative mating and wives' income trajectories. Furthermore, because of the specifications of group-based trajectory models, our control variables were measured before marriage or the onset of marriage. Therefore, we cannot consider the role of marital fertility in generating differences in wives' income trajectories. Instead, our models include several correlates of marital fertility, including the anticipated number of children.

\section{Discussion}

Prior studies have shown that spouses' relative education levels play an important role in shaping the trajectories of wives' labor market activities (Dribe and Nystedt 2013; Qian 2018; Van Bavel and Klesment 2017; Visser and Fasang 2018). These studies have explored the average relationship between educational assortative mating and income trajectories, controlling for race/ethnicity (Qian 2017, 2018; Qian and Shen 2021). Research has yet to examine whether and how the relationship between educational assortative mating and wives' income trajectories varies by race/ethnicity. Our study fills this gap.

Marked differences exist in the presence, prevalence, and shapes of prototypical longterm income trajectories among White, Black, and Hispanic wives. White wives are more likely than non-White wives to follow income trajectories consistent with a traditional gender division of labor, such as being a secondary earner. Conversely, Black wives are more likely than White and Hispanic wives to follow pathways consistent with a more gender-egalitarian division of 
labor, including pathways in which they are consistently an equal or primary earner. Unlike Black or Hispanic women, White wives are more likely to reduce their income contributions over time. This scaling back likely occurs because of the presence of young children in the household. White wives are more likely than Black and Hispanic wives to have the economic means to reduce their paid labor market activities following childbirth. This finding may also emerge because White women face larger wage penalties following transitions into motherhood than non-White women (England et al. 2016).

We also examine the association between educational assortative mating and wives' income trajectories. Women in educationally hypogamous unions are less likely to follow trajectories consistent with the traditional gender division of labor. These patterns align with prior work (Qian 2018; Van Bavel and Klesment 2017) and the predictions from exchange and bargaining theories. Wives with relatively higher education levels have a comparative advantage over their husbands in the labor market, which can prompt such wives to contribute more to couples' total income (Becker 1981; Lundberg and Pollak 1994; Miller 2020). Their higher earnings may also improve their bargaining position at home, which they can use to negotiate out of household chores and devote more time to the labor market (Miller 2020).

The relationship between educational assortative mating and trajectory group membership varies by race/ethnicity. This relationship appears stronger for White than for Black or Hispanic married women. Consistent with prior work for the overall population, White wives in hypergamous unions are least likely—and those in hypogamous unions are most likely— to follow trajectories consistent with the traditional gender division of labor. Deviating from the results for the overall population, our findings show that differences in Black and Hispanic wives' income trajectories largely occur between those in hypogamous and other unions. For 
example, Black women in hypogamous unions are less likely than other Black wives to be secondary earners, but the corresponding difference between those in homogamous and hypergamous unions is not statistically significant. Structural inequalities in the labor market might mean that Black couples rely more heavily on wives' contributions than White couples, resulting in a weaker link between educational assortative mating and wives' income trajectories for Black wives. Our study demonstrates the differential impact of family organization (i.e., educational assortative mating) on the socioeconomic well-being of families who belong to distinct racial/ethnic groups.

We also observe differences in the social processes that help explain variation in wives' income trajectories by educational assortative mating. White wives' socioeconomic status during young adulthood (including their educational attainment and employment before marriage) accounts for a considerable share of the differences in their trajectory group membership by educational assortative mating. This finding suggests that socioeconomic status at the point of marriage has implications for their socioeconomic well-being and labor market participation over the life course. By contrast, for Black wives, their partners' characteristics accounted for much of the variation in trajectory group membership by educational assortative mating. Inequalities in the labor market and Black men's disadvantageous positions make partner traits especially consequential for Black married women's socioeconomic well-being over the life course.

Finally, differences in gender beliefs suppress disparities in Hispanic women's probability of either being a consistently equal earner or decreasing their contribution to couples' total income. Hispanic couples in hypogamous unions may be seeking to "do gender" to compensate for their nonnormative educational arrangement. Most of the variation in trajectory 
membership by educational assortative mating remains for all racial/ethnic groups, net of all controls.

Overall, our findings underscore that educational assortative mating has important implications for White wives' economic contributions but plays a more limited role in determining the labor market outcomes of Black and Hispanic wives. Our study highlights the need for studies of the consequences of educational assortative mating to pay closer attention to heterogeneity across and within racial/ethnic groups. Finally, we echo recent calls dissuading the practice of using race/ethnicity as a control to explain away variation in socioeconomic outcomes (Cross forthcoming; Williams and Baker 2021). We must recognize that the average experiences of the population predominantly represent the experiences of White individuals and frequently exclude of the experiences of racial minority populations (Cross forthcoming).

Acknowledgments An early version of this article was presented at the 2022 annual meeting of the Population Association of America. We wholeheartedly thank Yue Qian for helpful comments on this manuscript.

Note Both authors share equal authorship. 


\section{References}

Adeyinka-Skold, S. (2020). Race, place, and relationship formation in the digital age. Du Bois Review, 17, 233-269.

Bany, J. A., Robnett, B., \& Feliciano, C. (2014). Gendered Black exclusion: The persistence of racial stereotypes among daters. Race and Social Problems, 6, 201-213.

Becker, G. S. (1974). A theory of marriage. In T. W. Schultz (Ed.), Economics of the family: Marriage, children, and human capital (pp. 299-351). Chicago, IL: University of Chicago Press.

Becker, G. S. (1981). A treatise on the family. Cambridge, MA: Harvard University Press.

Becker, H. S., \& Strauss, A. L. (1956). Careers, personality, and adult socialization. American Journal of Sociology, 62, 253-263.

Bertrand, M., Kamenica, E., \& Pan, J. (2015). Gender identity and relative income within households. Quarterly Journal of Economics, 130, 571-614.

Bittman, M., England, P., Sayer, L., Folbre, N., \& Matheson, G. (2004). When does gender trump money? Bargaining and time in household work. American Journal of Sociology, 109, 186-214.

Blair-Loy, M., \& DeHart, G. (2003). Family and career trajectories among African American female attorneys. Journal of Family Issues, 24, 908-933.

Breen, R., \& Salazar, L. (2011). Educational assortative mating and earnings inequality in the United States. American Journal of Sociology, 117, 808-843.

Brines, J. (1994). Economic dependency, gender, and the division of labor at home. American Journal of Sociology, 100, 652-688. 
Brown, S. L., Stykes, J. B., \& Manning, W. D. (2016). Trends in children's family instability, 1995-2010. Journal of Marriage and Family, 78, 1173-1183.

Bucca, M. (2018). Educational assortative mating and income inequality among Black and White families in the U.S., 1976-2017 [Unpublished manuscript]. Retrieved from https://mebucca.github.io/research/eam_us

Cancio, A. S., Evans, T. D., \& Maume, D. J., Jr. (1996). Reconsidering the declining significance of race: Racial differences in early career wages. American Sociological Review, 61, 541-556.

Carlson, D. L., Petts, R. J., \& Pepin, J. R. (2022). Changes in US parents' domestic labor during the early days of the COVID-19 pandemic. Sociological inquiry, 92, 1217-1244.

Cheng, S., Tamborini, C. R., Kim, C., \& Sakamoto, A. (2019). Educational variations in cohort trends in the Black-White earnings gap among men: Evidence from administrative earnings data. Demography, 56, 2253-2277.

Cherlin, A. (1978). Remarriage as an incomplete institution. American Journal of Sociology, 84, $634-650$.

Cherlin, A. J. (2021). Rising nonmarital first childbearing among college-educated women: Evidence from three national studies. Proceedings of the National Academy of Sciences, 118, e2109016118.

Chetty, R., Hendren, N., Jones, M. R., \& Porter, S. R. (2020). Race and economic opportunity in the United States: An intergenerational perspective. Quarterly Journal of Economics, 135, 711-783. 
Choi, K. H., Goldberg, R. E., \& Denice, P. A. (2022). Stability and outcome of interracial cohabitation before and after transitions to marriage. Demographic Research, 46, 9571006. https://doi.org/10.4054/DemRes.2022.46.33

Choi, K. H., \& Tienda, M. (2017). Marriage-market constraints and mate-selection behavior: Racial, ethnic, and gender differences in intermarriage. Journal of Marriage and Family, $79,301-317$.

Choi, K. H., \& Tienda, M. (2021). Gender and Educational Differentials in Marital Sorting of Hispanic Young Adults. The ANNALS of the American Academy of Political and Social Science, 696(1), 179-197.

Choi, S., Chung, I., \& Breen, R. (2020). How marriage matters for the intergenerational mobility of family income: Heterogeneity by gender, life course, and birth cohort. American Sociological Review, 85, 353-380.

Clawson, D., \& Gerstel, N. (2015). Unequal time: Gender, class, and family in employment schedules. New York, NY: Russell Sage Foundation.

Cohen, C. J., \& Nee, C. E. (2000). Educational attainment and sex differentials in African American communities. American Behavioral Scientist, 43, 1159-1206.

Collins, P. H. (2000). Blackfeminist thought: Knowledge, consciousness, and the politics of empowerment. New York, NY: Routledge.

Cooke, L. P. (2006). Doing gender context: Household bargaining and risk of divorce in Germany and the United States. American Journal of Sociology, 112, 442-472.

Coontz, S. (2005). Marriage, A history: From obedience to intimacy or how love conquered marriage. New York, NY: Viking. 
Coverdill, J. E., Kraft, J. M., \& Manley, K. S. (1996). Employment history, the sex typing of occupations, pay and change in gender-role attitudes: A longitudinal study of young married women. Sociological Focus, 29, 47-60.

Cross, C. J. (2019). Racial/ethnic differences in the association between family structure and children's education. Journal of Marriage and Family, 82, 691-712.

Cross, C. J. (forthcoming). Beyond the binary: Intra-racial diversity in family organization and Black adolescents' educational performance. Social Problems. Advance online publication. https://doi.org/10.1093/socpro/spab050

Damaske, S. (2011). A “major career woman"?: How women develop early expectations about work. Gender \& Society, 25, 409-430.

Damaske, S., \& Frech, A. (2016). Women's work pathways across the life course. Demography, $53,365-391$.

DiPrete, T. A., \& Buchmann, C. (2013). The rise of women: The growing gender gap in education and what it means for American schools. New York, NY: Russell Sage Foundation.

Dow, D. M. (2019). Mothering while Black: Boundaries and burdens and middle-class parenthood. Oakland: University of California Press.

Dribe, M., \& Nystedt, P. (2013). Educational homogamy and gender-specific earnings: Sweden, 1990-2009. Demography, 50, 1197-1216.

Edelman, M. W., \& Jones, J. M. (2004). Separate and unequal: America's children, race, and poverty. Future of Children, 14(2), 134-137.

Edin, K., Kefalas, M. J., \& Reed, J. M. (2004). A peek inside the black box: What marriage means for poor unmarried parents. Journal of Marriage and the Family, 66, 1007-1014. 
England, P., Bearak, J., Budig, M. J., \& Hodges, M. J. (2016). Do highly paid, highly skilled women experience the largest motherhood penalty? American Sociological Review, 81, $1161-1189$.

Esping-Andersen, G., \& Billari, F. C. (2015). Re-theorizing family demographics. Population and Development Review, 41, 1-31.

Esteve, A., García-Román, J., \& Permanyer, I. (2012). The gender-gap reversal in education and its effect on union formation: The end of hypergamy? Population and Development Review, 38, $535-546$.

Fisman, R., Iyengar, S. S., Kamenica, E., \& Simonson, I. (2006). Gender differences in mate selection: Evidence from a speed dating experiment. Quarterly Journal of Economics, 121, 673-697.

Fomby, P., Mollborn, S., \& Sennott, C. A. (2010). Race/ethnic differences in effects of family instability on adolescents' risk behavior. Journal of Marriage and Family, 72, 234-253.

Goldscheider, F., Bernhardt, E., \& Lappegård, T. (2015). The gender revolution: A framework for understanding changing family and demographic behavior. Population and Development Review, 41, 207-239.

Gonalons-Pons, P. (2015). Gender and class housework inequalities in the era of outsourcing: Hiring domestic work in Spain. Social Science Research, 52, 208-218.

Gonalons-Pons, P., \& Gangl, M. (2021). Marriage and masculinity: Male breadwinner culture, unemployment, and separation risk in 29 countries. American Sociological Review, 86, 465-502.

Gullickson, A. (2006). Education and Black-White interracial marriage. Demography, 43, 673-689. 
Hays, S. (1996). The cultural contradictions of motherhood. New Haven, CT: Yale University Press.

Herman, M. R., \& Campbell, M. E. (2012). I wouldn't, but you can: Attitudes toward interracial relationships. Social Science Research, 41, 343-358.

Hitsch, G. J., Hortaçsu, A., \& Ariely, D. (2010). Matching and sorting in online dating. American Economic Review, 100, 130-163.

Hummer, R. A., \& Hamilton, E. R. (2010). Race and ethnicity in fragile families. Future of Children, 20(2), 113-131.

Ishii-Kuntz, M., \& Coltrane, S. (1992). Remarriage, stepparenting, and household labor. Journal of Family Issues, 13, 215-233.

Jones, B. L., \& Nagin, D. S. (2013). A note on a Stata plugin for estimating group-based trajectory models. Sociological Methods \& Research, 42, 608-613. https://doi.org/10.1177/0049124113503141

Kane, E. W. (2000). Racial and ethnic variations in gender-related attitudes. Annual Review of Sociology, 26, 419-439.

Kao, G., \& Thompson, J. S. (2003). Racial and ethnic stratification in educational achievement and attainment. Annual Review of Sociology, 29, 417-442.

Kohler, U., Karlson, K. B., \& Holm, A. (2011). Comparing coefficients of nested nonlinear probability models. Stata Journal, 11, 420-438.

Landale, N. S., Oropesa, R. S., \& Bradatan, C. (2006). Hispanic families in the United States: Family structure and process in an era of family change. In M. Tienda \& F. Mitchell (Eds.), Hispanics and the future of America (pp. 138-178). Washington, DC: National Academies Press. https://doi.org/10.17226/11539 
Landor, A., \& Barr, A. (2018). Politics of respectability, colorism, and the terms of social exchange in family research. Journal of Family Theory \& Review, 10, 330-347.

Landry, B. (2000). Black working wives: Pioneers of the American family revolution. Berkeley: University of California Press.

Lin, K., \& Lundquist, J. (2013). Mate selection in cyberspace: The intersection of race, gender, and education. American Journal of Sociology, 119, 183-215.

Livingston, G., \& Brown, A. (2017). Intermarriage in the U. S. 50 years after Loving v. Virginia (Report). Washington DC: Pew Research Center.

Lu, Y., Wang, J. S.-H., \& Han, W.-J. (2017). Women's short-term employment trajectories following birth: Patterns, determinants, and variations by race/ethnicity and nativity. Demography, 54, 93-118.

Lundberg, S., \& Pollak, R. A. (1996). Bargaining and distribution in marriage. Journal of Economic Perspectives, 10(4), 139-158.

Mare, R. D. (1991). Five decades of educational assortative mating. American Sociological Review, 56, 15-32.

Marti, C. N. (2008). Latent postsecondary persistence pathways: Educational pathways in American two-year colleges. Research in Higher Education, 49, 317-336.

McDaniel, A., DiPrete, T. A., Buchmann, C., \& Shwed, U. (2011). The Black gender gap in educational attainment: Historical trends and racial comparisons. Demography, 48, 889914.

McLanahan, S., \& Jacobsen, W. (2015). Diverging destinies revisited. In P. R. Amato, A. Booth, S. M. McHale, \& J. Van Hook (Eds.), National symposium on family issues: Vol. 5. Families in an era of increasing inequality: Diverging destinies (pp. 3-23). Cham, 
Switzerland: Springer International Publishing. https://doi.org/10.1007/978-3-319-08308$\underline{7} 1$

Miller, R. N. (2020). Educational assortative mating and time use in the home. Social Science Research, 90, 102440. https://doi.org/10.1016/j.ssresearch.2020.102440

Mize, T. D. (2019). Best practices for estimating, interpreting, and presenting nonlinear interaction effects. Sociological Science, 6, 81-117.

Nagin, D. S. (2005). Group-based modeling and development. Cambridge, MA: Harvard University Press.

Oppenheimer, V. K. (1988). A theory of marriage timing. American Journal of Sociology, 94, $563-591$.

Pepin, J. R., \& Cotter, D. A. (2018). Separating spheres? Diverging trends in youth's gender attitudes about work and family. Journal of Marriage and Family, 80, 7-24.

Peterson, R. R. (1996). A re-evaluation of the economic consequences of divorce. American Sociological Review, 61, 528-536.

Qian, Y. (2017). Educational assortative mating and female breadwinning trajectories: A groupbased trajectory analysis. In C. L. Scott \& S. L. Blair (Eds.), Contemporary perspectives in family research: Vol. 11. Intimate relationships and social change: The dynamic nature of dating, mating, and coupling (pp. 95-123). Bingley, UK: Emerald Publishing.

Qian, Y. (2018). Educational assortative mating and income dynamics in couples: A longitudinal dyadic perspective. Journal of Marriage and Family, 80, 607-621.

Qian, Z., \& Shen, Y. (2021, April). Educational advantage and earnings lead? Assortative mating and spousal pay gap. Paper presented at the annual meeting of the Population Association of America. 
Raley, R. K., \& Bumpass, L. L. (2003). The topography of the divorce plateau: Levels and trends in union stability in the United States after 1980. Demographic Research, 8, 245-260. https://doi.org/10.4054/DemRes.2003.8.8

Raley, R. K., \& Sweeney, M. M. (2020). Divorce, repartnering, and stepfamilies: A decade in review. Journal of Marriage and Family, 82, 81-99.

Raley, R. K., Sweeney, M. M., \& Wondra, D. (2015). The growing racial and ethnic divide in U.S. marriage patterns. Future of Children, 25(2), 89-109.

Reid, L. L., \& Padavic, I. (2005). Employment exits and the race gap in young women's employment. Social Science Quarterly, 86, 1242-1260.

Schneider, D., Harknett, K., \& Stimpson, M. (2019). Job quality and the educational gradient in entry into marriage and cohabitation. Demography, 56, 451-476.

Schwartz, C. R. (2010). Earnings inequality and the changing association between spouses' earnings. American Journal of Sociology, 115, 1524-1557.

Schwartz, C. R., \& Han, H. (2014). The reversal of the gender gap in education and trends in marital dissolution. American Sociological Review, 79, 605-629.

Schwartz, C. R., \& Mare, R. D. (2005). Trends in educational assortative marriage from 1940 to 2003. Demography, 42, 621-646.

Shafer, K. (2012). Unique matching patterns in remarriage: Educational assortative mating among divorced men and women. Journal of Family Issues, 34, 1500-1515.

Slopen, N., Shonkoff, J., Albert, M. A., Yoshikawa, H., Jacobs, A., Stoltz, R., \& Williams, D. R. (2016). Racial disparities in child adversity in the U.S.: Interactions with family immigration history and income. American Journal of Preventive Medicine, 50, 47-56. 
Smock, P. J. (2000). Cohabitation in the United States: An appraisal of research themes, findings, and implications. Annual Review of Sociology, 26, 1-20.

Storer, A., Schneider, D., \&. Harknett, K. (2020). What explains racial/ethnic inequality in job quality in the service sector? American Sociological Review, 85, 537-572.

Sun, S. (2020). Who can access "good" jobs? Racial disparities in employment among young men who work in paid care. Annals of the American Academy of Political and Social Science, 688, 55-76.

Sweeney, M. M. (2002). Two decades of family change: The shifting economic foundations of marriage. American Sociological Review, 67, 132-147.

Sweeney, M. M. (2010). Remarriage and stepfamilies: Strategic sites for family scholarship in the 21st century. Journal of Marriage and Family, 72, 667-684.

Thompson, E., Hanson, T. L., \& McLanahan, S. S. (1994). Family structure and child wellbeing: Economic resources vs. parental behaviors. Social Forces, 73, 221-242.

Tichenor, V. (2005). Maintaining men's dominance: Negotiating identity and power when she earns more. Sex Roles, 53, 191-205.

Udansky, M. L. (2011). The gender-equality paradox: Class and incongruity between workfamily attitudes and behaviors. Journal of Family Theory \& Review, 3, 163-178.

Van Bavel, J., \& Klesment, M. (2017). Educational pairings, motherhood, and women's relative earnings in Europe. Demography, 54, 2331-2349.

Van Bavel, J., Schwartz, C. R., \& Esteve, A. (2018). The reversal of the gender gap in education and its consequences for family life. Annual Review of Sociology, 44, 341-360.

Visser, M., \& Fasang, A. E. (2018). Educational assortative mating and couples' linked late-life employment trajectories. Advances in Life Course Research, 37, 79-90. 
Wagmiller, R. L., Jr. (2007). Race and the spatial segregation of jobless men in urban America. Demography, 44, 539-562.

Weisshaar, K., \& Cabello-Hutt, T. (2020). Labor force participation over the life course: The long-term effects of employment trajectories on wages and the gendered payoff of employment. Demography, 57, 33-60.

West, C., \& Fenstermaker, S. (1995). Doing difference. Gender \& Society, 9, 8-37.

West, C., \& Zimmerman, D. H. (1987). Doing gender. Gender \& Society, 1, 125-151.

Western, B., \& Sirois, C. (2019). Racialized re-entry: Labor market inequality after incarceration. Social Forces, 97, 1517-1542.

Williams, D. T., \& Baker, R. S. (2021). Family structure, risks, and racial stratification in poverty. Social Problems, 68, 964-985. 


\section{TABLES}

Table 1 Summary statistics for hypergamous ("hyper"), homogamous ("homo"), and hypogamous ("hypo") unions by race/ethnicity

\begin{tabular}{|c|c|c|c|c|c|c|c|c|c|}
\hline & \multicolumn{3}{|c|}{ Non-Hispanic White } & \multicolumn{3}{|c|}{ Non-Hispanic Black } & \multicolumn{3}{|c|}{ Hispanic } \\
\hline & Hyper & Homo & Нypo & Hyper & Homo & Hyро & Hyper & Homo & Hypo \\
\hline$n$ & 604 & 966 & 414 & 237 & 374 & 195 & 194 & 350 & 135 \\
\hline$\%$ & 30 & 49 & 21 & 29 & 47 & 24 & 28 & 51 & 20 \\
\hline$\%$ Both Parents & 79 & 82 & 82 & 47 & 54 & 54 & 66 & 68 & 69 \\
\hline$\%<$ High School Mother & 31 & 28 & 23 & 57 & 57 & 53 & 75 & 76 & 68 \\
\hline \% Employed Mother & 71 & 72 & 71 & 64 & 69 & 69 & 61 & 53 & 61 \\
\hline Gender Beliefs Index & -0.03 & -0.11 & -0.20 & -0.06 & -0.16 & -0.24 & 0.02 & 0.04 & -0.04 \\
\hline$\%$ Will Work at Age 35 & 83 & 84 & 88 & 93 & 91 & 96 & 90 & 84 & 94 \\
\hline \multicolumn{10}{|l|}{ No. of Expected Children } \\
\hline None & 7 & 7 & 13 & 9 & 6 & 6 & 6 & 4 & 3 \\
\hline One & 8 & 10 & 10 & 14 & 16 & 11 & 7 & 11 & 14 \\
\hline Two or more & 86 & 84 & 77 & 77 & 79 & 83 & 87 & 86 & 83 \\
\hline Total & 100 & 100 & 100 & 100 & 100 & 100 & 100 & 100 & 100 \\
\hline \multicolumn{10}{|l|}{ Respondent's Education } \\
\hline$<$ High school & 32 & 9 & - & 42 & 8 & - & 53 & 35 & - \\
\hline High school graduate & 41 & 48 & 26 & 35 & 60 & 18 & 29 & 35 & 38 \\
\hline Some college & 28 & 14 & 42 & 24 & 23 & 48 & 17 & 18 & 50 \\
\hline $4+$ years college & - & 29 & 31 & - & 9 & 34 & - & 12 & 12 \\
\hline Total & 100 & 100 & 100 & 100 & 100 & 100 & 100 & 100 & 100 \\
\hline \multicolumn{10}{|l|}{ Employment Before Marriage } \\
\hline Employed & 44 & 49 & 55 & 36 & 43 & 52 & 33 & 39 & 39 \\
\hline Unemployed & 53 & 48 & 42 & 62 & 56 & 46 & 64 & 55 & 55 \\
\hline Missing & 3 & 2 & 4 & 2 & 2 & 1 & 3 & 6 & 6 \\
\hline Total & 100 & 100 & 100 & 100 & 100 & 100 & 100 & 100 & 100 \\
\hline$\%$ Premarital Birth & 9 & 7 & 8 & 49 & 51 & 45 & 21 & 16 & 21 \\
\hline \multicolumn{10}{|l|}{ Age at Marriage } \\
\hline $15-19$ & 36 & 25 & 15 & 29 & 13 & 4 & 49 & 33 & 19 \\
\hline $20-24$ & 43 & 41 & 46 & 43 & 49 & 39 & 30 & 38 & 53 \\
\hline $25-29$ & 13 & 22 & 23 & 14 & 20 & 25 & 14 & 17 & 19 \\
\hline $30+$ & 8 & 12 & 16 & 14 & 17 & 32 & 7 & 12 & 10 \\
\hline Total & 100 & 100 & 100 & 100 & 100 & 100 & 100 & 100 & 100 \\
\hline \multicolumn{10}{|l|}{ Husband's Income } \\
\hline Below the poverty line & 18 & 14 & 14 & 28 & 25 & 25 & 21 & 18 & 21 \\
\hline $100 \%$ to $199 \% \times$ poverty & 9 & 6 & 8 & 10 & 13 & 8 & 12 & 12 & 12 \\
\hline $200 \% \times$ poverty line & 73 & 80 & 78 & 62 & 62 & 67 & 67 & 70 & 67 \\
\hline Total & 100 & 100 & 100 & 100 & 100 & 100 & 100 & 100 & 100 \\
\hline \multicolumn{10}{|l|}{ Age Gap Between Spouses } \\
\hline Wife is older & 11 & 19 & 20 & 19 & 22 & 23 & 16 & 19 & 40 \\
\hline Husband $>$ wife: $\leq 4$ years & 61 & 60 & 59 & 55 & 59 & 51 & 57 & 59 & 46 \\
\hline Husband > wife: $5+$ years & 28 & 20 & 21 & 27 & 19 & 26 & 27 & 22 & 14 \\
\hline Total & 100 & 100 & 100 & 100 & 100 & 100 & 100 & 100 & 100 \\
\hline$\%$ Cohabited With Spouse & 26 & 30 & 36 & 29 & 29 & 32 & 19 & 29 & 24 \\
\hline
\end{tabular}

Notes: Data come from the NLSY79, 1979-2018. Means and percentages are weighted; $n$ values are not weighted; the totals may not sum precisely to 100.0 because of rounding. 
Table 2 Measures of group-based trajectory model fit

\begin{tabular}{|c|c|c|c|c|c|c|}
\hline & \multicolumn{6}{|c|}{ Number of Groups in Model } \\
\hline & 3 & 4 & 5 & 6 & 7 & 8 \\
\hline \multicolumn{7}{|c|}{ White Women $(n=1,984)$} \\
\hline \multicolumn{7}{|l|}{ APP } \\
\hline Group 1 & .915 & .783 & .793 & .788 & .822 & .783 \\
\hline Group 2 & .873 & .878 & .825 & .820 & .782 & .789 \\
\hline Group 3 & .905 & .840 & .825 & .821 & .790 & .753 \\
\hline Group 4 & & .889 & .788 & .869 & .743 & .772 \\
\hline Group 5 & & & .888 & .775 & .828 & .680 \\
\hline Group 6 & & & & .855 & .844 & .813 \\
\hline Group 7 & & & & & .897 & .821 \\
\hline Group 8 & & & & & & .894 \\
\hline \multicolumn{7}{|l|}{$\mathrm{BIC}$} \\
\hline Person-years & $-83,228.73$ & $-82,894.32$ & $-82,507.38$ & $-82,331.83$ & $-82,267.00$ & $-82,138.10$ \\
\hline Persons & $-83,211.99$ & $-82,872.00$ & $-82,479.49$ & $-82,298.36$ & $-82,227.95$ & $-82,093.47$ \\
\hline \multicolumn{7}{|c|}{ Black Women $(n=806)$} \\
\hline \multicolumn{7}{|c|}{ APP } \\
\hline Group 1 & .884 & .860 & .854 & .782 & .646 & .705 \\
\hline Group 2 & .871 & .773 & .762 & .682 & .716 & 676 \\
\hline Group 3 & .874 & .753 & .822 & .865 & .644 & .644 \\
\hline Group 4 & & .871 & .760 & .778 & .918 & .716 \\
\hline Group 5 & & & .850 & .755 & .722 & .890 \\
\hline Group 6 & & & & .858 & .755 & .698 \\
\hline Group 7 & & & & & .865 & .733 \\
\hline Group 8 & & & & & & .822 \\
\hline \multicolumn{7}{|l|}{$\mathrm{BIC}$} \\
\hline Person-years & $-24,995.42$ & $-24,993.78$ & $-24,858.62$ & $-24,809.20$ & $-24,790.76$ & $-24,778.72$ \\
\hline Persons & $-24,981.08$ & $-24,914.66$ & $-24,834.73$ & $-24,780.53$ & $-24,757.31$ & $-24,740.49$ \\
\hline \multicolumn{7}{|c|}{ Hispanic women $(n=679)$} \\
\hline \multicolumn{7}{|c|}{ APP } \\
\hline Group 1 & .931 & .873 & .820 & .811 & .808 & .725 \\
\hline Group 2 & .891 & .779 & .805 & .789 & .721 & .772 \\
\hline Group 3 & .872 & .824 & .812 & .788 & .839 & .702 \\
\hline Group 4 & & .877 & .764 & .794 & .774 & .795 \\
\hline Group 5 & & & .856 & .804 & .812 & .683 \\
\hline Group 6 & & & & .846 & .754 & .749 \\
\hline Group 7 & & & & & .880 & .768 \\
\hline Group 8 & & & & & & .866 \\
\hline \multicolumn{7}{|l|}{$\mathrm{BIC}$} \\
\hline Person-years & $-26,216.51$ & $-26,153.67$ & $-26,109.53$ & $-26,081.22$ & $-26,054.60$ & $-26,067.90$ \\
\hline Persons & $-26,200.44$ & $-26,132.24$ & $-26,082.75$ & $-26,049.08$ & $-26,017.11$ & $-26,025.05$ \\
\hline
\end{tabular}

Notes: This table provides two sets of statistics used to evaluate group-based trajectory models that estimate solutions based on different numbers of groups: the average posterior probabilities (APP) of assignment into each group and the Bayesian information criteria (BIC). The models in bold indicate our preferred solution for each racial/ethnic group. 
Table 3 Distribution of trajectories of wives' share of couples' total annual income, by wives' race/ethnicity

\begin{tabular}{|c|c|c|c|c|c|c|c|c|}
\hline Wife's Race/Ethnicity & $\begin{array}{c}\text { Wife Is } \\
\text { Consistently } \\
\text { Low } \\
\text { Secondary } \\
\text { Earner }\end{array}$ & $\begin{array}{c}\text { Wife Is } \\
\text { Consistently } \\
\text { High } \\
\text { Secondary } \\
\text { Earner }\end{array}$ & $\begin{array}{c}\text { Wife } \\
\text { Consistently } \\
\text { Equal } \\
\text { Earner }\end{array}$ & $\begin{array}{c}\text { Wife Is } \\
\text { Consistently } \\
\text { Primary } \\
\text { Earner }\end{array}$ & $\begin{array}{l}\text { Wife Increases } \\
\text { From Equal to } \\
\text { Primary } \\
\text { Earner }\end{array}$ & $\begin{array}{l}\text { Wife Increases } \\
\text { From } \\
\text { Secondary to } \\
\text { Equal Earner }\end{array}$ & $\begin{array}{c}\text { Wife } \\
\text { Decreases } \\
\text { From Equal to } \\
\text { Secondary } \\
\text { Earner }\end{array}$ & $\begin{array}{c}\text { Wife } \\
\text { Decreases } \\
\text { From Primary } \\
\text { to Secondary } \\
\text { Earner }\end{array}$ \\
\hline Non-Hispanic White & 27.1 & 20.5 & $26.5^{\mathrm{b}, \mathrm{c}}$ & $5.9^{\mathrm{c}}$ & - & - & 15.7 & $4.1^{\mathrm{b}}$ \\
\hline Non-Hispanic Black & 28.8 & - & $40.4^{\mathrm{a}, \mathrm{c}}$ & 7.2 & 13.5 & - & - & $10.0^{\mathrm{a}}$ \\
\hline Hispanic & 27.0 & - & $34.8^{\mathrm{a}, \mathrm{b}}$ & $9.2^{\mathrm{a}}$ & - & 14.9 & 14.0 & - \\
\hline
\end{tabular}

Note: Table shows the weighted percentages of White, Black, and Hispanic married women following each prototypical trajectory from Figure 1.

a Statistically significantly different from non-Hispanic White women $(p<.05)$.

${ }^{\mathrm{b}}$ Statistically significantly different from non-Hispanic Black women $(p<.05)$.

${ }^{\mathrm{c}}$ Statistically significantly different from Hispanic women $(p<.05)$. 
Table 4 Predicted probabilities of trajectory membership by race/ethnicity and educational assortative mating

\begin{tabular}{|c|c|c|c|c|c|c|}
\hline & $\begin{array}{c}\text { Unadjusted } \\
\text { Differences in } \\
\text { AMEs }\end{array}$ & $\begin{array}{c}\text { Family } \\
\text { Background }\end{array}$ & $\begin{array}{l}\text { Gender } \\
\text { Beliefs }\end{array}$ & $\begin{array}{c}\text { Early } \\
\text { Adulthood } \\
\text { SES } \\
\end{array}$ & Partner Traits & $\begin{array}{c}\text { Total } \\
\text { Explained } \\
\text { Share } \\
\end{array}$ \\
\hline \multicolumn{7}{|l|}{ Non-Hispanic White } \\
\hline \multicolumn{7}{|l|}{ Consistently low secondary earner } \\
\hline Hypergamous versus homogamous & 11.6 & 3.5 & 6.9 & 24.6 & -7.7 & 27.3 \\
\hline Homogamous versus hypogamous & 8.4 & 2.1 & 13.7 & 23.3 & 8.2 & 47.3 \\
\hline Hypergamous versus hypogamous & 20.0 & 2.9 & 9.7 & 24.1 & -1.0 & 35.7 \\
\hline \multicolumn{7}{|c|}{ Decreasing from equal to secondary earner } \\
\hline Homogamous versus hypogamous & 4.9 & -3.3 & 5.4 & -21.4 & -2.0 & -21.3 \\
\hline \multicolumn{7}{|l|}{ Consistently the equal earner } \\
\hline Homogamous versus hypogamous & -11.3 & 1.1 & 9.1 & 9.3 & -1.7 & 17.7 \\
\hline Hypergamous versus hypogamous & -19.8 & 1.5 & 6.6 & 18.1 & 2.7 & 28.9 \\
\hline \multicolumn{7}{|l|}{ Non-Hispanic Black } \\
\hline \multicolumn{7}{|l|}{ Consistently low secondary earner } \\
\hline Homogamous versus hypogamous & 14.6 & 1.2 & 0.3 & 14.5 & 11.3 & 27.3 \\
\hline Hypergamous versus hypogamous & 19.2 & 2.5 & 7.4 & 25.1 & 8.3 & 43.2 \\
\hline \multicolumn{7}{|l|}{ Increasing from equal to primary earner } \\
\hline Hypergamous versus homogamous & -4.6 & -0.5 & 4.7 & -11.9 & -0.5 & -8.2 \\
\hline Hypergamous versus hypogamous & -8.6 & 1.4 & 1.7 & 2.3 & -5.8 & -0.4 \\
\hline \multicolumn{7}{|c|}{ Decreasing from primary to secondary earner } \\
\hline Homogamous versus hypogamous & -4.6 & -0.1 & -6.9 & -12.4 & 61.1 & 41.8 \\
\hline \multicolumn{7}{|l|}{ Consistently primary earner } \\
\hline Hypergamous versus hypogamous & -3.7 & -1.4 & 0.0 & -78.9 & 71.5 & -8.8 \\
\hline \multicolumn{7}{|l|}{ Hispanic } \\
\hline \multicolumn{7}{|l|}{ Consistently low secondary earner } \\
\hline Hypergamous versus hypogamous & 10.0 & 2.9 & 2.3 & 10.3 & 23.7 & 39.1 \\
\hline \multicolumn{7}{|c|}{ Decreasing from equal to secondary status } \\
\hline Homogamous versus hypogamous & -5.9 & 19.0 & -13.9 & 11.5 & 14.7 & 31.3 \\
\hline Hypergamous versus hypogamous & -7.4 & 9.4 & -10.5 & 29.9 & 18.0 & 46.8 \\
\hline \multicolumn{7}{|l|}{ Consistently the primary earner } \\
\hline Homogamous versus hypogamous & -7.7 & -4.2 & 6.9 & -17.2 & 34.5 & 19.9 \\
\hline Hypergamous versus hypogamous & -6.9 & -6.2 & 7.0 & -26.5 & 56.9 & 31.1 \\
\hline
\end{tabular}


Fig. 1 Group-based trajectories of the share of income earned by wives, by race/ethnicity. The figure is estimated using the results from our preferred trajectory models.

(a) White

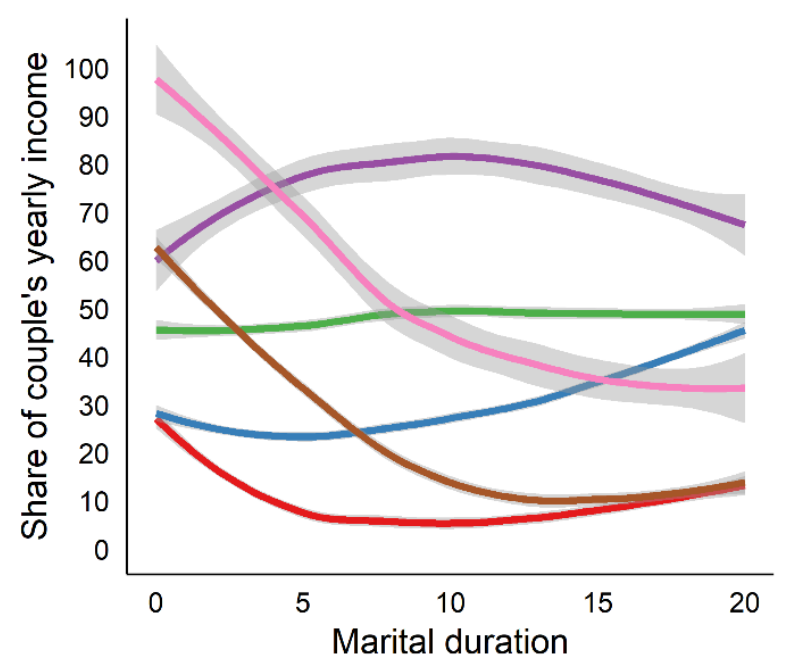

(c) Hispanic

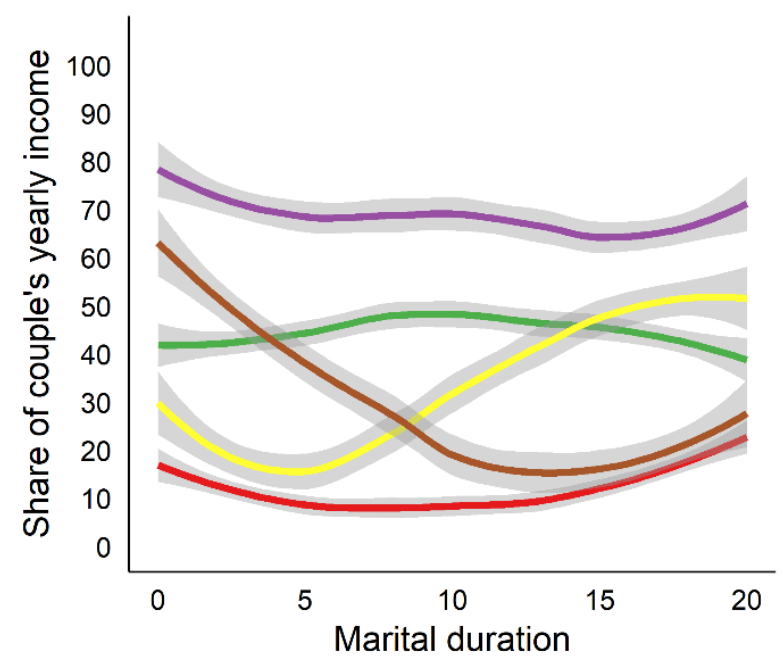

(b) Black

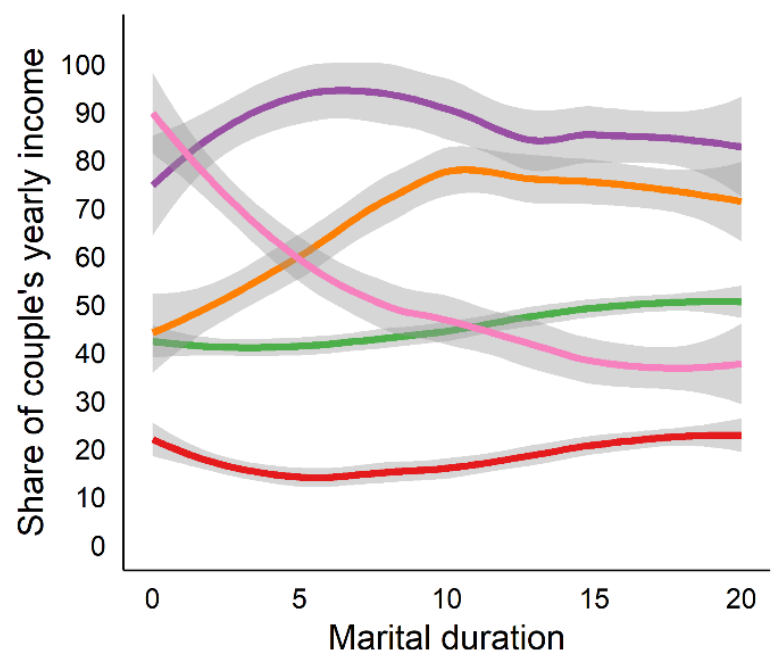

Trajectories

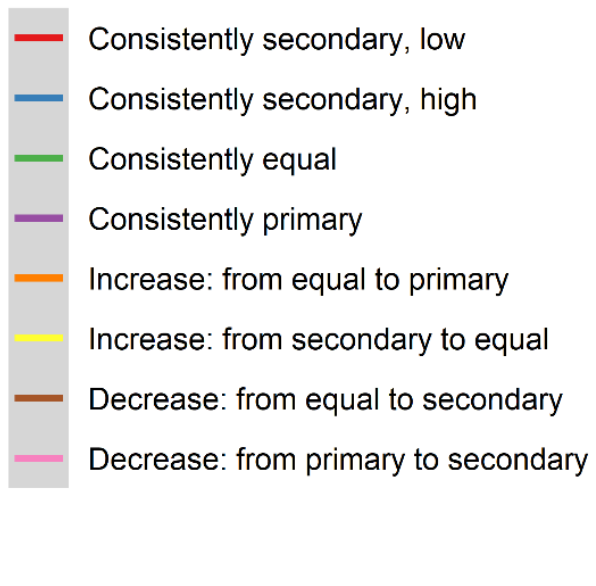

Models include linear, squared, and cubed measures of marital duration. Lines indicate the LOESS-smoothed average share over time within each group (95\% confidence intervals are shaded in gray). Table 3 provides the share of each racial/ethnic group following each trajectory; online appendix Table A3 provides the parameters describing each trajectory's shape. 
Fig. 2 Predicted percentages of trajectory group membership, by educational assortative mating and race/ethnicity.

\section{(a) White}

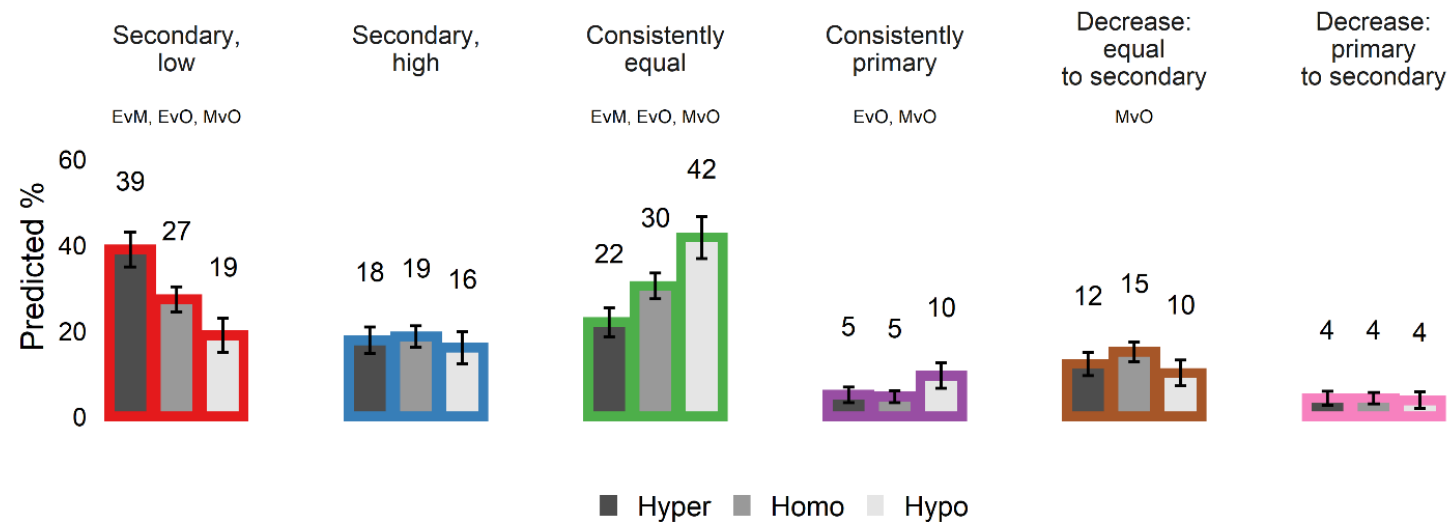

(b) Black

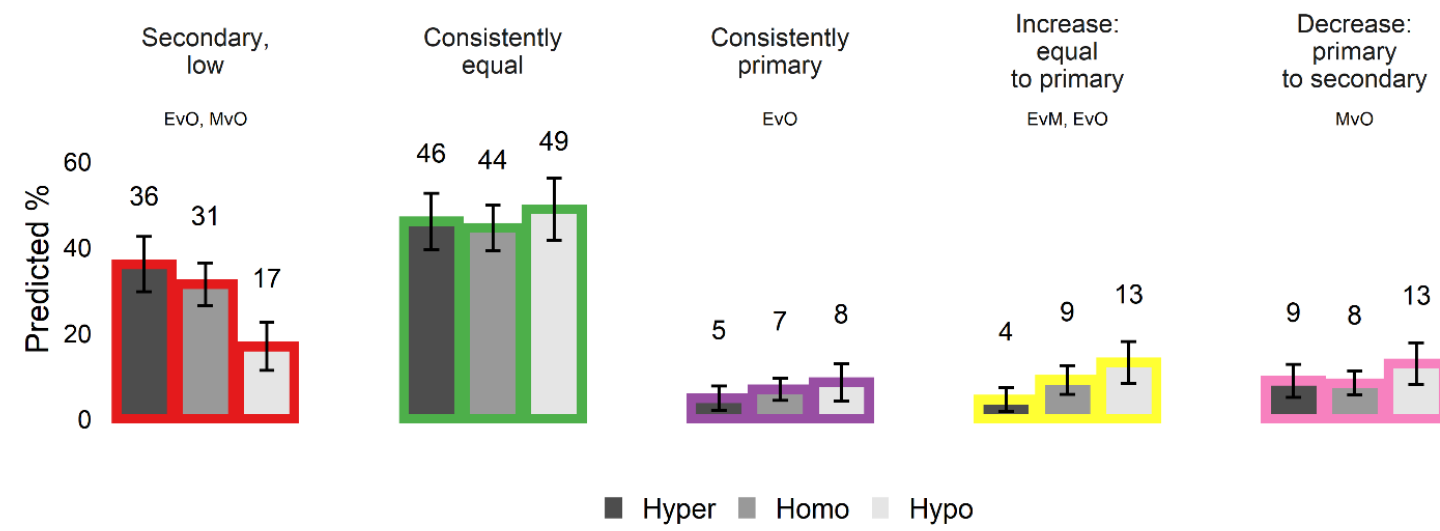

(c) Hispanic

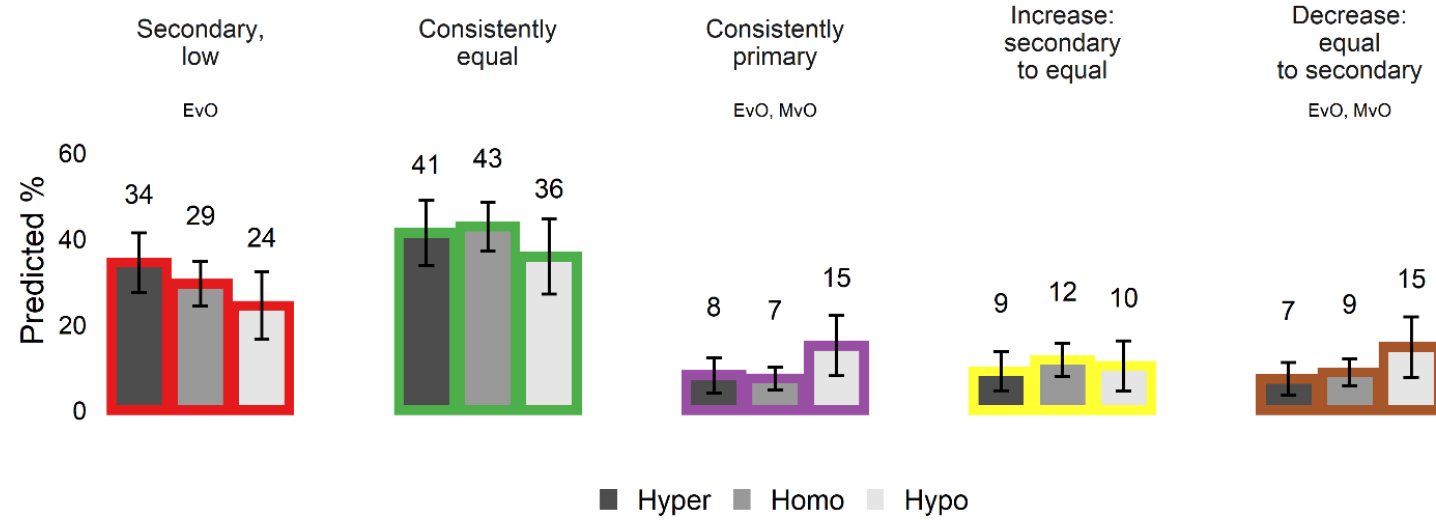

The predicted percentages of membership in each trajectory group are estimated using the coefficients from our reduced-form multinomial logistic regression models stratified by race/ethnicity (Model 1 in Tables A4-A6). Statistically significant differences by educational assortative mating groups $(p<.05)$ are shown: $E$ denotes hypergamy; $M$ denotes homogamy; $O$ denotes hypogamy. For instance, $E v O$ denotes significant differences between wives in hypergamous versus hypogamous unions. Whiskers represent $95 \%$ confidence intervals. 